\title{
Centenario de Los cuentos de mi tía Panchita de Carmen Lyra (1920 - 2020): contexto educativo, literario y político de la primera edición de una obra
}

Rubio Torres, Carlos

Centenario de Los cuentos de mi tía Panchita de Carmen Lyra (1920 - 2020): contexto educativo, literario y político de la primera edición de una obra

Revista Educación, vol. 44, núm. 2, 2020

Universidad de Costa Rica, Costa Rica

Disponible en: http://www.redalyc.org/articulo.oa?id=44062184024

DOI: https://doi.org/10.15517/revedu.v44i2.41197

Esta obra está bajo una Licencia Creative Commons Atribución-NoComercial-SinDerivar 3.0 Internacional. 


\title{
Centenario de Los cuentos de mi tía Panchita de Carmen Lyra (1920 - 2020): contexto educativo, literario y político de la primera edición de una obra
}

\author{
A Centennial of Los cuentos de mi tía Panchita (Tales of My Aunt Panchita), by Carmen Lyra (1920 - 2020): The \\ Educational, Literary and Political Context of the First Edition
}

Carlos Rubio Torres

Universidad de Costa Rica, Costa Rica

carlos.rubio@ucr.ac.cr

iD http://orcid.org/000-0002-6175-1401

\author{
DOI: https://doi.org/10.15517/revedu.v44i2.41197 \\ Redalyc: http://www.redalyc.org/articulo.oa?id=44062184024
}

Recepción: 28 Marzo 2020

Aprobación: 18 Mayo 2020

\section{RESUMEN:}

En el año 2020 se conmemoran cien años de la publicación del libro Los cuentos de mi tía Panchita, escrito por Carmen Lyra y editado por Joaquín García Monge. En este ensayo se presenta la descripción de algunas condiciones educativas, literarias y políticas las cuales caracterizaron la época de su primera edición y que permitieron se difundiera una obra dedicada a la niñez, donde se recopilaban cuentos populares recogidos en Costa Rica. Se destaca la importancia que se dio al folclor, la injerencia de la publicación de la revista San Selerín, la fundación de la Cátedra de Literatura Infantil en la Escuela Normal y el papel que desempeñó la autora en los movimientos sociales que provocaron la caída de la dictadura de los hermanos Tinoco. Se evidencia que esta colección de cuentos contiene recreaciones de argumentos que fueron aportados, previamente, por Fernán Caballero en España y Joel Chandler Harris en Estados Unidos. También se estudian otras fuentes como los cuentos populares españoles recopilados por Antonio Rodríguez Almodóvar. Aún en el siglo XXI, Los cuentos de mi tía Panchita puede ser considerado como un libro políticamente incorrecto pues hace uso de construcciones gramaticales y léxico que personas conservadoras podrían considerar inapropiadas para la niñez. Es una obra que refleja el afán por difundir las culturas populares y que representa las posturas vanguardistas de su escritora y editor.

Palabras Clave: Cuento, Patrimonio cultural inmaterial, Folclor, Literatura folclórica, Niñez, Educación cultural, Educación y ocio.

\section{Abstract:}

The year 2020 commemorates one-hundred years since the Costa Rican classic, Los cuentos de mi tia Panchita (Tales of my Aunt Panchita), by Carmen Lyra and edited by Joaquín García Monge, was first published. This article sets forth some of the educational, literary and political circumstances that led to the publication of a singular literary work for children that compiled Costa Rica 's most celebrated folk tales. Emphasis is made on folklore and the importance of its publication in the children's periodical, San Selerin, which led to the establishment of a Children's Literature Department at the Costa Rican Teachers College and also looks at the role of the author in the different social movements that led to the fall of the Tinoco brothers' dictatorship. The collection of stories recreates arguments previously contributed by authors Fernan Caballero from Spain and Joel Chandler Harris from the United States. Other sources are also studied, such as a compilation of popular Spanish Folk and Fairly Tales by Antonio Rodríguez Almodóvar. Even now, in the 21 century, Los cuentos de mi tía Panchita may be deemed to be politically incorrect, given its use of grammatical construction and vocabulary of conservative individuals that may be considered inappropriate for children. Yet, it is a literary work that reflects the eagerness of the author and editor to disseminate popular culture and represent their avant-garde positions.

KEYWORDS: Fairy Tale, Intangible Heritage, Folklore, Folk Literature, Childhood, Cultural Education, Education and Recreation.

\section{INTRODUCCIÓN}

El $1^{\circ}$ de abril de 1920 apareció un comercial en el número 16 de la revista Repertorio Americano, allíse anunció la reciente publicación de un nuevo libro de Carmen Lyra titulado Los cuentos de mi tía Panchita. Se trataba de cuentos populares costarricenses recogidos por la escritora y educadora que "era la llamada a hacerlo" (Lyra, 
1920, p. 245). Es el primer indicio de una obra que, cien años después de su primera edición, constituye un referente de la literatura infantil costarricense, pues con ella se consolida la tradición de escribir y publicar textos primordialmente recreativos, sin ostensible intención didáctica, dirigidos a las jóvenes generaciones. Son cuentos que se trasladaron de generación a generación, en diferentes culturas del mundo, lo cual le permite a la persona lectora descubrir, como si se tratara de un encriptado hallazgo, algún afán moralizante. Como señaló Peña (2009), se trata de historias viejas escritas con un lenguaje popular, campechano, rico en modismos, refranes y giros regionales con que la autora logra un estilo propio.

Este ensayo no guarda ninguna pretensión crítica sobre la obra de Lyra; eso corresponde desarrollarlo en otro documento. Se presenta una síntesis de las condiciones que permitieron a dos profesionales, específicamente a Carmen Lyra y Joaquín García Monge, a escribir y editar Los cuentos de mi tía Panchita, un libro que tal como lo afirma Díaz (2020) se vuelve un texto entrañable para público de diversas edades. Por eso, se muestra una descripción de algunas condiciones educativas, literarias y políticas de Costa Rica en que facilitaron, en el año 1920, la publicación de una obra de recopilaciones de cuentos populares. También, se sustenta que en los Cuentos de encantamiento, de Fernán Caballero (1988) y The Complete Tales of Uncle Remus, de Joel Chandler Harris (1983) se evidencian los argumentos que utilizó Carmen Lyra para dar a conocer, con un modismos propios del español costarricense de su época, Los cuentos de mi tía Panchita.

Resultaba esencial el estudio de un ejemplar de la primera edición. En Costa Rica, hasta el momento, se ha hallado ninguno, sin embargo existe un ejemplar del libro de Lira [sic] (1920) en la Biblioteca Nacional de Maestros de Argentina ${ }^{[1]}$. Fue una obra que llevó el subtítulo Cuentos populares recogidos en Costa Rica, publicada por García Monge y Cía. Editores en la colección Ediciones de autores costarricenses, de 160 páginas sin ilustraciones.

En Costa Rica, específicamente en la Biblioteca Nacional, se localizó el anuncio de Repertorio Americano del $1^{\circ}$ de abril de 1920; las dos ediciones que circularon en 1936 y una edición póstuma de 1956, entre los documentos más antiguos.

Lyra y García Monge dedicaron sus vidas a la labor magisterial, razón por la cual se considera una prioridad presentar un esbozo de su trabajo en las aulas y su labor como editores de obras destinadas a docentes y estudiantes.

\section{LA VOCACIÓN EDUCATIVA}

María Isabel Carvajal Castro, quien firmó sus obras con el seudónimo de Carmen Lyra, nació en San José, Costa Rica, en 1887 y falleció en la Ciudad de México en 1949. Al respecto su descendiente, Quesada (2017), afirma:

Nace María Isabel Carvajal Castro en una casa de adobe en el Barrio Amón, un 15 de enero de 1888. Su madre Elena Carvajal Castro fue una de esas mujeres a las que les tocó criar a su hija a finales del siglo XIX, ya que su padre no la reconoció al nacer. Años más tarde, su progenitor quiso darle el apellido, pero ella no lo aceptó. (p. 3)

Esta escritora obtuvo el grado de maestra normal en el Colegio Superior de Señoritas y ejerció en una escuela rural en San José de la Montaña, en la provincia de Heredia, y en la Escuela de Niñas ubicada en el Edificio Metálico, en la capital, tal como lo consigna Chase (1999). Gracias a un decreto firmado por el presidente Julio Acosta en mayo de 1924, inauguró en abril de 1925, la Escuela Maternal de Costa Rica, institución pionera de la educación preescolar del país. Allí se desempeñó como directora y docente y llevó a la práctica una visión pedagógica ecléctica, en la que no solo prevaleció el pensamiento de Montessori, pues integró el aporte de Froebel, Decroly y las hermanas Agazzi, en búsqueda de la transformación social, tal como lo refiere Rubio (2019). Debido a su ingreso al Partido Comunista y su decidida militancia política fue destituida en 1933. En ese mismo año escribió dos documentos didácticos dirigidos al público adulto: $E l$ grano de oro y El peón. En 1936 inició labores en el Patronato Nacional de la Infancia con gamines, término 
con el que entonces se señalaba despectivamente a menores que deambulaban por las calles. Puede así colegirse que la autora se perfiló, durante toda su vida, como educadora con una clara visión humanista.

Por otra parte, el libro Los cuentos de mi tía Panchita fue editado por Joaquín García Monge, quien nació en Desamparados en 1881 y falleció en San José en 1958. Estudió en el Instituto Pedagógico de la Universidad de Chile y se desempeñó como profesor en el Edificio Metálico, el Liceo de Costa Rica y el Colegio Superior de Señoritas, en San José.

Mora (1988) expresó que García Monge nació “para ser Maestro” (p. 24), pues su quehacer magisterial se extendió durante toda su existencia y ejecutó una encomiable labor como docente y director de la Escuela Normal de Costa Rica. Incluso, esa vocación magisterial se reflejó en la publicación de Repertorio Americano, revista que circuló entre setiembre de 1919 hasta poco antes de su muerte y se convirtió en una cátedra abierta a la diversidad de pensamiento, en una época en la que Costa Rica carecía de universidad.

Ferrero (1988) sostuvo que García Monge tomó sustento de los ideales de Herbart, Spencer y Pestalozzi y además fue uno de los principales difusores de la obra de Dewey. Con base en los ideales de Martí, concibió que la educación tenía, como fin fundamental, la realización integral del ser humano, por lo que instaba a pensar, a despertar el apetito por el aprendizaje y orientar la curiosidad frente a los hechos de la vida.

Así encontramos que tanto la autora como el editor respondieron a una vocación educativa y que la publicación de Los cuentos de mi tía Panchita reflejó la necesidad de ofrecer a la niñez, y al público en general, un texto que permitiera acercarse, de manera gozosa al solaz, la reflexión y el desarrollo del pensamiento creativo y crítico. Sus aportes educativos también se manifestaron en la fundación de una Cátedra de Literatura Infantil en la Escuela Normal de Costa Rica, hecho que constituye un hito pues ofreció a docentes de la época la posibilidad de estudiar la poesía, el cuento o el teatro como expresiones estéticas necesarias para la niñez, tal como lo expresa Rubio (2018).

\section{LA CÁTEDRA DE LITERATURA INFANTIL Y LA PRIMACÍA DEL DISCURSO FOLCLÓRICO}

El presidente Alfredo González Flores creó, por decreto en 1914, la Escuela Normal de Costa Rica. Fue una institución que abrió sus puertas, en la ciudad de Heredia en 1915, y que se caracterizó por mantener una posición vanguardista en la formación magisterial. Joaquín García Monge fue uno de sus profesores y fundó allí, entre 1917 y 1919 , una Cátedra de Literatura Infantil.

No se ha encontrado ningún documento en el cual se evidencie, con claridad, el año de fundación de la Cátedra. Pérez (1985) expresa que fue en 1917 y Dobles (1984) en 1919. Tal confusión es comprensible pues, en ese período, se instauró una dictadura encabezada por los hermanos Federico y José Joaquín Tinoco que trajo como consecuencia una convulsa coyuntura en la que, incluso, García Monge tuvo que salir del país.

De manera contundente se señala: "La literatura infantil en Costa Rica comenzó en la cátedra" (Dobles, 1984, p. 93), por lo que constituyó un semillero de profesionales que se dedicaron a la creación literaria y la difusión de los hábitos de lectura para la niñez y la juventud. Por ese motivo se sostiene:

Los verdaderos fundadores de la Literatura Infantil en Costa Rica son Joaquín García Monge y Carmen Lyra, cada uno en el campo de su interés. Carmen Lyra, además, inicia el teatro para niños y publica el primer tomo de cuentos folclóricos. (Pérez, 1985, p. 106)

Resulta meritorio destacar que las personas quienes, posteriormente dirigieron la Cátedra, no solo se concentraron en labores docentes, pues también desarrollaron un destacado aporte a la creación de narrativa, poesía, teatro o ensayo ubicables dentro de la literatura infantil. Es el caso de Carmen Lyra, pues compuso obras de teatro como Ensueño de Navidad o el libro Los cuentos de mi tía Panchita; Carlos Luis Sáenz fue autor de obras como Mulita Mayor o El abuelo cuentacuentos; Adela Ferreto publicó Tolo, el gigante viento Norte o el estudio Las fuentes de la literatura infantil y el mundo mágico; María Teresa Obregón fue descrita por su hija María Eugenia Dengo (2011) como una maestra que tenía "el don y la gracia” (p. 67) para narrar 
cuentos infantiles o Margarita Dobles, fue una investigadora que forjó un encomiable aporte teórico con libros como Literatura infantil y Por qué cuento y canto para mis niños. La trascendencia de Joaquín García Monge también se observó en jóvenes que, a pesar de que nunca trabajaron en la Cátedra, recibieron su apoyo y, con el paso del tiempo, escribieron notables textos literarios como María Leal de Noguera con Cuentos viejos o Joaquín Gutiérrez Mangel con Cocorí.

En la Escuela Normal prevaleció el interés por fomentar la lectura en sus estudiantes. Basta conocer el número de títulos que llegó a atesorar en su biblioteca. Tal como lo consigna Pérez (2012) allí se reunió un acervo de 652 libros de literatura española y portuguesa, 199 de literatura inglesa, 192 de literatura clásica, 97 de literatura italiana, 521 de literatura hispanoamericana, 188 de literatura costarricense y 538 de literatura francesa; con estos datos se puede inferir que, en esa época, era una biblioteca voluminosa, con la cual se aspiraba a no solo formar docentes que conocieran su disciplina pues se deseaba que, también, fueran personas dotadas de una amplia sensibilidad hacia la literatura y las artes.

A pesar de que no se guardan documentos en los que se consignen las prácticas educativas ni los textos estudiados durante los inicios de la Cátedra de Literatura Infantil, resulta esclarecedor un aporte que, en 1948, hace García Monge:

Pero hay otra literatura, la folclórica. Al niño la literatura que más le conviene y le interesa es la folclórica, de su gente, de su tierra. Por eso, de los autores nacionales, que serían los que más hayan penetrado en el saber del pueblo y le hayan dado expresiones nuevas a la poesía, en el cuento, en el teatro infantil. Y si los autores de Costa Rica (nuestro caso inmediato) no alcanzan, pues habría que recurrir a los de Hispanoamérica y España que más cerca del alma del niño estén. (García Monge, citado por Ferrero, 1988, p. 133).

Congruente con esa línea, Ferreto (1984) también indica que la fuente primaria de la literatura infantil es el folclor. El interés por el rescate de las tradiciones folclóricas alcanzó mayor auge en el siglo XIX y tuvo repercusiones en los inicios del siglo XX, cuando se fundaba la Cátedra de Literatura Infantil. Al respecto, Balach Blanch (2003) revela que los folcloristas europeos encontraron inspiración, a partir de 1846, en los estudios del anticuario William John Thoms, quien propuso el término folclor para denominar a la literatura popular y las antigüedades populares e instó a recopilar canciones, cuentos, refranes, adivinanzas, leyendas o tradiciones de tipo romántico o naturalista. Con el paso del tiempo, apunta también Balach Blanch, el folclor fue estudiado por profesionales de la filología, la etnología y la antropología y se integró al contexto universitario y científico.

Es importante mencionar que, a partir de 1812, los hermanos Grimm (2006) publicaron el primer volumen de sus Cuentos infantiles y del hogar y lograron, con ese valioso acopio de relatos, poner por escrito una tradición que generalmente se limitaba a la transmisión oral, conservada en la memoria de personas que no pertenecían al contexto académico. Estos hechos, ocurridos en Europa, repercutieron de manera importante en la fundación de la Cátedra de Literatura Infantil de la Escuela Normal de Costa Rica.

Lyra (1999) en el ensayo La Cenicienta, publicado originalmente en 1914, en la revista Pandemonium, elaboró una elegía de los cuentos provenientes del folclor europeo, africano y norteamericano y describió emotivamente a personajes surgidos en las páginas de Perrault, los hermanos Grimm, Madame d'Aulnoy, Madame Leprince de Beaumont o Joel Chandler Harris y así reafirmó la preponderancia del pensamiento folclórico que se verá, años después, reflejado en la cátedra en la que ella ejercería como profesora. Evocaba así la autora:

Bendito cuento este de Cenicienta y su zapatilla de cristal que dejó perdida en la escala del palacio del rey cuando oyó sonar la primera campanada que indicaba la medianoche! Lo maravilloso que encierra posee el encanto de las bellezas que no producen ningún bien material; la gentil inutilidad de la espuma que palpita sobre la copa que mantiene la bebida generosa; la de anunciación del fruto que hay en la seda de los pétalos. (Lyra, 1999; pp. 94 - 95)

La recopilación del folclor se manifestó en la Cátedra de Literatura Infantil y en publicaciones de la época dirigidas a la niñez, especialmente en la revista San Selerín como se explicará a continuación. 


\section{San Selerín: EL hallazgo de UN tío Conejo APóCrifo}

Guiadas por el ejemplo que José Martí había impregnado a la revista La edad de oro en 1889, dos maestras costarricenses publicaron San Selerín, definido por sus creadoras como "un periódico para niños" (San Selerín, 1912, p. 3), el cual, mucho más allá de ofrecer material didáctico, ofreció la posibilidad de leer relatos, poemas y observar imágenes que provocaron la recreación y el desarrollo del goce estético en su público.

Esta revista se dio a conocer en dos épocas. La primera de esas épocas salió desde 1912 hasta 1913, bajo la dirección de Carmen Lyra y Lilia González. La segunda época, desde 1923 hasta 1924, y fue dirigida por las educadoras ya mencionadas y Joaquín García Monge.

Allí no solo circularon artículos didácticos y aleccionadores, también se publicaron textos vinculados al folclor y los cuentos maravillosos, tal como consta en la Tabla 1:

TABLA 1

Cuentos y poemas, vinculados a cuentos maravillosos, de la Revista San Selerín

\begin{tabular}{|c|c|c|c|c|c|}
\hline Título & $\begin{array}{l}\text { Persona } \\
\text { autora }\end{array}$ & Número & Época & Fecha & \begin{tabular}{|l|} 
Número \\
de \\
página
\end{tabular} \\
\hline Almendrita & $\begin{array}{l}\text { Sin la firma } \\
\text { de Hans } \\
\text { Christian } \\
\text { Andersen } \\
\end{array}$ & 6 & I & $\begin{array}{l}15 \text { de } \\
\text { octubre de } \\
1912\end{array}$ & $7-14$ \\
\hline El carlanco & $\begin{array}{l}\text { Fernán } \\
\text { Caballero }\end{array}$ & 8 & I & \begin{tabular}{|l|}
15 de \\
noviembre \\
de 1912 \\
\end{tabular} & $14-17$ \\
\hline $\begin{array}{l}\text { Cenicienta o } \\
\text { la zapatilla } \\
\text { de cristal }\end{array}$ & $\begin{array}{l}\text { Charles } \\
\text { Perrault }\end{array}$ & 10 & I & $\begin{array}{l}15 \text { de abril } \\
\text { de } 1913\end{array}$ & $1-10$ \\
\hline $\begin{array}{l}\text { Las hadas } \\
\text { del bosque }\end{array}$ & $\begin{array}{l}\text { Apaikán, } \\
\text { seudónimo } \\
\text { de María } \\
\text { Fernández } \\
\text { de Tinoco } \\
\end{array}$ & 14 & I & $\begin{array}{l}15 \text { de junio } \\
\text { de } 1913\end{array}$ & $3-5$ \\
\hline $\begin{array}{l}\text { Hansely } \\
\text { Gretel }\end{array}$ & $\begin{array}{l}\text { Hermanos } \\
\text { Grimm }\end{array}$ & 14 & I & \begin{tabular}{|l|}
15 de junio \\
de 1913 \\
\end{tabular} & $7-16$ \\
\hline $\begin{array}{l}\text { La Bella } \\
\text { Durmiente } \\
\text { del bosque }\end{array}$ & $\begin{array}{l}\text { Charles } \\
\text { Perrault }\end{array}$ & 15 & I & $\begin{array}{l}15 \text { de julio } \\
\text { de } 1913\end{array}$ & $9-16$ \\
\hline $\begin{array}{l}\text { Las bodas } \\
\text { de la } \\
\text { Cucarachita }\end{array}$ & \begin{tabular}{|l|} 
Lemuel \\
Gullivier (se \\
cree que es \\
seudónimo \\
de Carlos \\
Luis Sáenz) \\
\end{tabular} & 3 & II & $\begin{array}{l}1^{\circ} \text { de mayo } \\
\text { de } 1923\end{array}$ & $15-16$ \\
\hline $\begin{array}{l}\text { Caperucita } \\
\text { Roja }\end{array}$ & \begin{tabular}{|l|}
$\begin{array}{l}\text { Gabriela } \\
\text { Mistral }\end{array}$ \\
\end{tabular} & 4 & II & \begin{tabular}{|l|}
15 de mayo \\
de 1923
\end{tabular} & $8-9$ \\
\hline $\begin{array}{l}\text { El zurrón } \\
\text { que cantaba }\end{array}$ & $\begin{array}{l}\text { Sin la firma } \\
\text { de Fernán } \\
\text { Caballero }\end{array}$ & 5 & II & $\begin{array}{l}15 \text { de junio } \\
\text { de } 1923\end{array}$ & $5-7$ \\
\hline $\begin{array}{l}\text { La rana } \\
\text { encantada }\end{array}$ & $\begin{array}{l}\text { Sin la firma } \\
\text { de los } \\
\text { hermanos } \\
\text { Grimm }\end{array}$ & 8 & II & $\begin{array}{l}15 \text { de julio } \\
\text { de } 1923\end{array}$ & $12-16$ \\
\hline
\end{tabular}

Fuente: Elaboración propia.

Se observa, entonces, la congruencia que guardaba la línea editorial de San Selerín con la Cátedra de Literatura Infantil, aunque empezó a circular dos años antes de la apertura de la Escuela Normal, pues se recopilaron cuentos motivados en la tradición oral de Europa. 
Se debe resaltar que en San Selerín apareció el personaje tío Conejo. En la revista $\mathrm{N}^{\circ} 11$, del $1^{\circ}$ de mayo de 1913, se presentó una nota introductoria sobre los cuentos del escritor norteamericano Joel Chandler Harris, quien escribió historias narradas por personas afrodescendientes que vivían, en los Estados Unidos, en el siglo XIX, en condición de esclavitud.

Chandler Harris dio a conocer un personaje llamado Brother Rabbit, o bien de manera abreviada, Brer Rabbit, que sirvió como modelo para crear el personaje de tío Conejo. El primero de esos relatos apareció firmado como Arreglo de San Selerín y los demás no tienen datos sobre su autoría, tal como se aprecia en la Tabla 2:

TABLA 2

Tío Conejo en la revista San Selerín

\begin{tabular}{|c|c|c|c|c|c|}
\hline Título & Autora & Número & Época & Fecha & $\begin{array}{l}\text { Número } \\
\text { de } \\
\text { página }\end{array}$ \\
\hline $\begin{array}{l}\text { Aventuras de tio } \\
\text { Conejo (Nota } \\
\text { introductoria sobre los } \\
\text { Cuentos de Joel } \\
\text { Chandler Harris) }\end{array}$ & $\begin{array}{l}\text { Arreglo de San } \\
\text { Selerín }\end{array}$ & 11 & I & $\begin{array}{l}1^{\circ} \text { de mayo } \\
\text { de } 1913\end{array}$ & 14 \\
\hline El viejo de la montaña & $\begin{array}{l}\text { Arreglo de San } \\
\text { Selerín }\end{array}$ & 11 & I & $\begin{array}{l}1^{\circ} \text { de mayo } \\
\text { de } 1913\end{array}$ & $14-16$ \\
\hline $\begin{array}{l}\text { Tio Conejo ayuda a } \\
\text { tía Tortuga }\end{array}$ & Anónimo & 13 & I & $\begin{array}{l}1^{\circ} \text { de junio } \\
\text { de } 1913\end{array}$ & $14-15$ \\
\hline $\begin{array}{l}\text { Tía Tortuga ayuda a } \\
\text { tio Conejo }\end{array}$ & Anónimo & 13 & I & $\begin{array}{l}1^{\circ} \text { de junio } \\
\text { de } 1913\end{array}$ & $15-16$ \\
\hline $\begin{array}{l}\text { El caballo de tio } \\
\text { Conejo }\end{array}$ & Anónimo & 16 & I & \begin{tabular}{|l|}
$1^{\circ}$ de \\
agosto de \\
1913 \\
\end{tabular} & $4-6$ \\
\hline $\begin{array}{l}\text { Mister Caballo y tía } \\
\text { Zorra }\end{array}$ & Anónimo & 19 & I & \begin{tabular}{|l}
15 de \\
setiembre \\
de 1913
\end{tabular} & $12-14$ \\
\hline $\begin{array}{l}\text { El paseo de la familia } \\
\text { de tio Conejo }\end{array}$ & Anónimo & 2 & II & $\begin{array}{l}15 \text { de abril } \\
\text { de } 1923 \\
\end{array}$ & $12-14$ \\
\hline Tio Conejo y tía Boa & $\begin{array}{l}\text { Sin la firma de } \\
\text { María Leal de } \\
\text { Noguera. } \\
\text { Aparece } \\
\text { completo en su } \\
\text { libro Cuentos } \\
\text { viejos. } \\
\end{array}$ & 3 & II & $\begin{array}{l}1^{\circ} \text { de mayo } \\
\text { de } 1923\end{array}$ & $7-8$ \\
\hline $\begin{array}{l}\text { Tio Conejoy } \\
\text { compañia }\end{array}$ & Anónimo & 6 & II & $\begin{array}{l}15 \text { de junio } \\
\text { de } 1923\end{array}$ & $17-18$ \\
\hline $\begin{array}{l}\text { Cómo tio Conejo les } \\
\text { jugó sucio a tía } \\
\text { Ballena y tio Elefante }\end{array}$ & $\begin{array}{l}\text { Sin la firma de } \\
\text { Carmen Lyra. } \\
\text { Aparece } \\
\text { Completo en } \\
\text { Cuentos de mi tia } \\
\text { Panchita } \\
\end{array}$ & 10 & II & $\begin{array}{l}15 \text { de } \\
\text { agosto de } \\
1923\end{array}$ & $3-4$ \\
\hline $\begin{array}{l}\text { Los primos de tio } \\
\text { Conejo se escapan de } \\
\text { la escuela }\end{array}$ & Anónimo & 21 & II & $\begin{array}{l}15 \text { de junio } \\
\text { de } 1924\end{array}$ & $14-16$ \\
\hline
\end{tabular}

Fuente: Elaboración propia.

Es válido plantear, a manera de conjetura, que la mayoría de los cuentos de tío Conejo, publicados en San Selerin, fueron escritos por Carmen Lyra, debido a la uniformidad del estilo y solo uno de ellos, Tío Conejo y tía Boa, fue elaborado por María Leal de Noguera, pues forma parte de su obra Cuentos viejos.

Hay construcciones gramaticales que recuerdan el lenguaje popular de Los cuentos de mi tía Panchita, como en El caballo de tío Conejo, cuyo argumento recuerda Tío Conejo ennoviado, en el cual se expresa: "Pero tío 
Conejo pensó: ¿a dónde irán a parar estas mieles? No me la hacen buena... Y así le contestó que estaba muy mal de los pies y que no podía caminar" (Anónimo, 1913, agosto 1, p. 4); o Los primos de tío Conejo se escapan de la escuela, donde se dice: “¿Conque esas tenemos? Ahorita mismo voy donde la niña Tulita Conejo, y le contaré, vagabundos y grandes tales por cuales”, (Anónimo, 1924, junio 15, p 15). Y como es usual, el personaje central es un pillo que siempre se sale con la suya gracias a sus argucias e ingenio.

Asimismo, en el No 10 del 15 de agosto de 1923, se da a conocer Cómo tío Conejo les jugó sucio a tía Ballena y tio Elefante, el cual no está registrado en la primera edición de Los cuentos de mi tía Panchita y aparece en las dos ediciones de esa obra publicadas en 1936.

Es posible pensar que Lyra y Leal de Noguera, exalumnas de García Monge en el Colegio Superior de Señoritas, creyeran que esos textos eran arreglos de maestras que carecían de valor literario y que dieran a conocer sus primeras versiones de estos relatos en San Selerín, sin considerar que se trataba de obras que, con el paso del tiempo, alcanzarían méritos en la literatura nacional y trascenderían el inicial propósito de servir de entretenimiento para la niñez.

Por esos motivos, es conveniente plantear que existe un tío Conejo apócrifo, un habitante de las páginas de San Selerín que resulta prácticamente desconocido, pues se encuentra fuera del canon tradicionalmente consignado en los libros de Lyra, Leal de Noguera, Sáenz o Ferreto, y otras personas que relataron y recrearon sus aventuras.

La publicación de San Selerín representa un preámbulo, una especie de borrador, de tío Conejo, uno de los personajes emblemáticos de Los cuentos de mi tía Panchita. No en vano Omar Dengo señalaba la trascendencia de esta publicación en 1912:

'San Selerín'... no hará campañas políticas, ni obra de educación popular, ni luchas por la justicia y el progreso, ni labores de engrandecimiento comercial, ni nada de todo eso que hacen los hombres, pero por sobre todo eso, entre el bullicio de una ronda, a manera de mensajes para lo futuro, encumbrará los papalotes de su alegría y su pureza. (Dengo, 2015, p. 289).

Una obra como Los cuentos de mi tía Panchita, entendida como un libro de cuentos populares, solo se pudo publicar en un contexto político que facilitara la libertad de expresión, en el que la autora y el editor pudieran hacer uso de su voluntad creativa, por ese motivo se hará una reseña del panorama social de Costa Rica, entre 1917 y 1920.

\section{LA CAÍDA DE LA DICTADURA Y EL RETORNO DE LA LIBERTAD DE EXPRESIÓN}

Costa Rica estuvo gobernada, entre 1917 y 1919, por la dictadura de los hermanos Federico y José Joaquín Tinoco, régimen tildado como "odioso" por González (2006, p. 70), debido a los diferentes actos de represión contra todo aquel que le manifestara oposición. Fue un movimiento liderado por miembros de las clases políticas y económicas dominantes que impusieron un golpe de Estado al presidente Alfredo González Flores, quien se había atrevido a fundar el Banco Nacional y a dictar leyes que aplicaban mayor rigurosidad en el pago de impuestos.

Miembros de la intelectualidad sufrieron amenazas y vejaciones. Omar Dengo se rehusó a dirigir la Escuela Normal, y en su lugar, trabajó como maestro en una escuela rural. García Monge fue destituido del puesto de director de la Normal y se vio obligado a viajar, por una temporada, a los Estados Unidos. Además, entre los hechos que enardecieron al magisterio costarricense estuvo el uso de una tarjeta conocida como la tercerilla que consistía en el rebajo de la tercera parte del salario, la cual era sustituida con un documento que servía para comprar únicamente en algunos establecimientos comerciales, cuyos precios eran elevados.

Como es comprensible, era un ambiente social en el cual no existían las condiciones adecuadas para publicar libros y revistas para difundir la libertad de pensamiento; o bien, ideas que podían resultar subversivas contra el modelo político dominante. 
Fueron varias las maestras quienes valientemente idearon y acudieron a actos que contribuyeron a la caída de los Tinoco, entre ellas estaba Carmen Lyra. Estudiosos como Oconitrillo (1980) y Lemistre (2011) señalaron que esta educadora y escritora participó en manifestaciones públicas que estaban totalmente prohibidas a la población, principalmente a las mujeres. Así fue cómo tuvo un papel decisivo en la llamada Semana heroica, desde el lunes 11 hasta el viernes 13 de junio de 1919.

A pesar de que el 12 de junio el periódico oficialista La Información anunció que el presidente estaba decidido a reorganizar y despedir a miembros del personal docente, estudiantes del Colegio Superior de Señoritas, el Liceo de Costa Rica y el Colegio Seminario, siguieron a varias educadoras que, al parecer, eran encabezadas por Carmen Lyra. En esa ocasión, la joven Fresia Brenes, hija del poeta Roberto Brenes Mesén, recibió la amenaza de la policía cuando intentaba pronunciar un discurso en el Parque Morazán. Varias maestras acudieron en su ayuda y se armó una revuelta, en la cual los oficiales lanzaron chorros de agua y las manifestantes contestaron con pedradas y armas de fuego. Ese mismo día, el gobierno cesó a Carmen Lyra y otras profesoras. Al día siguiente, tal como describieron González y Sáenz (1977) y Dengo (2011), María Isabel Carvajal fue una de las principales lideresas que encabezó una marcha callejera que culminó con la quema del edificio del periódico La Información.

El impacto de estas manifestaciones no tardó en sentirse, pues el 10 de agosto de 1919 Joaquín Tinoco fue asesinado en una esquina de avenida sétima, calle 3, a escasos metros de la casa de Carmen Lyra. Por su parte, Federico Tinoco, junto a su esposa María Fernández (quien había publicado un cuento de hadas en San Selerín, con el seudónimo de Apaikán) se marchó a Europa y entregó el poder.

Se estableció un gobierno provisional, liderado por Francisco Aguilar Barquero y, posteriormente, se eligió al presidente Julio Acosta García. Como consecuencia, Joaquín García Monge fue nombrado Secretario de Educación Pública e inició a partir del $1^{\circ}$ de setiembre de 1919, la publicación de su memorable Repertorio Americano, que constituyó una cátedra abierta y una tribuna para el libre pensamiento, no solo en nuestro país pues su relevancia fue conocida en el contexto iberoamericano.

Carmen Lyra, junto a las educadoras Lilia González y Matilde Carranza, recibió una beca para perfeccionar sus estudios pedagógicos en países europeos. Al respecto, la Cartera de Relaciones Exteriores emitió un documento en el que se consideró que la mujer merecía igual relación que el hombre:

... en todo aquello que favorece las relaciones con el Estado [; que la señorita María Isabel Carvajal dio una lección memorable de carácter en lucha contra la tiranía [y que se da fe de] sus dotes literarios y su reconocido amor a la causa de la enseñanza primaria [por lo que se le concede] su viaje a uno de los países de Europa [,] el valor de los pasajes y una pensión equivalente a setenta y cinco dólares mensuales por el término de un año. (Lemistre, 2011, p. 160)

Poco se sabe de lo que hizo Carmen Lyra en el viejo continente. Tan solo se guarda, en el Archivo Nacional de Costa Rica, su pasaporte sellado en Francia. Se supone que recibió un seminario en la Universidad de La Sorbona, en París, con la pedagoga María Montessori, aunque se carezca de documentos para demostrarlo. Lo cierto es que regresó al país con un conocimiento profundo de la filosofía montessoriana.

Se puede aseverar que, en 1920, la escritora gozó de un período de reconocimiento público, debido a su liderazgo político, hecho poco usual en una mujer de su tiempo. Fue un ambiente adecuado, desde el punto de vista social, para que se publicara su libro de cuentos dirigido a la niñez. Tanto ella como su editor, Joaquín García Monge, obtuvieron el apoyo gubernamental y pudieron así desenvolverse en condiciones de libertad, necesarias para dar a conocer su voluntad creativa. Así se dio a conocer este libro de cuentos populares recogidos en Costa Rica que tienen raíces profundas en relatos procedentes de otras culturas, como se observará a continuación. 


\section{La sabiduría ANCestral de tía Panchita}

Dos son las fuentes primordiales que se vislumbran en los argumentos del libro de la tía Panchita, pues los trece primeros cuentos tienen vínculos con los Cuentos de encantamiento de la escritora española Fernán Caballero (1988) y los diez restantes, cuyo personaje central es tío Conejo, con cuentos del norteamericano Joel Chandler Harris (1983).

Peña (2020) explica que Fernán Caballero fue una escritora que nació en Suiza en 1796, aunque optó por la nacionalidad española y pasó la mayor parte de su vida en Andalucía, específicamente en Sevilla. Se llamó Cecilia Böhl de Faber y Ruiz de Larrea, pero recurrió a un seudónimo masculino, como lo hicieron muchas escritoras de su tiempo, para publicar sus obras y ganarse un sitio en el ámbito editorial y académico, dominado en ese entonces primordialmente por varones. Entabló amistad con autores como Washington Irving y conoció la riqueza cultural de esa tierra en sitios como en los que se reunía la alta alcurnia andaluza como el Alcázar de Sevilla, el Real Teatro de la Maestranza o bajo la torre de La Giralda. También conoció los barrios y los campos de esa tierra, donde dialogó con personas humildes y atesoró, con sumo cuidado, la riqueza de su oralidad: rimas, adivinanzas, oraciones, leyendas y cuentos. Debe recordarse, asimismo, que la escuela romántica, predominante en la intelectualidad de ese entonces, postulaba el cuido y rescate de las tradiciones populares.

Elaboró novelas de costumbres como La gaviota o Clemencia y ganó reconocimiento internacional por la recopilación de textos populares, publicados en 1859, con el título de Cuentos y poesías populares andaluces. De manera posterior a su fallecimiento, ocurrido en 1877, circularon sus conocidos Cuentos de encantamiento, que se volvieron muy conocidos entre la niñez.

La autora costarricense admite que conocía la obra de la española. En la introducción de Los cuentos de mi tía Panchita expresa: "Recuerdo el cuento de 'La Cucarachita Mandinga' ('La Hormiguita', de Fernán Caballero, vaciado en un molde quizá americano, quizá tico solamente), que no nos cansábamos de escuchar”, (Lyra, 2020, p. 19). Asimismo, como ya se mencionó, en San Selerín se publicó el cuento El carlanco, de Caballero.

Se puede inferir que Carmen Lyra reelaboró, con el lenguaje popular costarricense de principios del siglo $\mathrm{XX}$, algunos cuentos de esta escritora andaluza. Por ejemplo, El lirio azul, versión valenciana de Caballero (1988), fue narrado como La flor del olivar, por Lyra (2020); El pájaro de la verdad, de Caballero (1988), como El pájaro dulce encanto, por Lyra (2020); Juan Cigarrón, de Caballero (1988), como El tonto de las adivinanzas, de Lyra (2020); Juan Soldado, de Caballero (1988), como Uvieta, de Lyra (2020); La hormiguita, de Caballero (1988) como La Cucarachita Mandinga, de Lyra (2020); e incluso, ambas autoras dan el mismo título a sus respectivas versiones del cuento La suegra del diablo.

En el texto La hormiguita, Caballero introduce una nota al pie de página, en la cual explica que "ratompérez [sic] es un bichito gris muy inofensivo, tímido, que no hace ruido y solo sabe huir” (Caballero, 1988, p. 101) y más allá de eso también fue un personaje creado por Luis Coloma, conocido como el Padre Coloma (1911), por encargo de la reina María Cristina de Habsburgo, como regalo a su hijo, el futuro Rey Alfonso XIII, pues había perdido su primer diente. Como lo explica Gavaldá (2019), ese sacerdote señaló que el Ratón Pérez vivía en una caja de galletas en la Confitería Prast, en el número 8 de la calle Arenal de Madrid. Actualmente, allí se encuentra un museo dedicado al mítico ratón que es, al mismo tiempo, personaje del libro de María Isabel Carvajal. Leal (2020) señala que Ratón Pérez forma parte del imaginario infantil universal y que, a aproximadamente a partir de la década del 40 del siglo XX, se extendió en América la costumbre de dejar el primer diente caído bajo la almohada como una ofrenda para el fantástico personaje.

No debe buscarse solamente el origen de los Cuentos de mi tía Panchita en los Cuentos de encantamento de Caballero, pues se leen argumentos semejantes en otros relatos antiguos de diferentes regiones, por ejemplo, en los cuentos de los hermanos Grimm (2006). Este asunto merece ser tratado en otro estudio. 
Específicamente en España, en la región de Andalucía, Rodríguez recopila dos colecciones de cuentos populares publicados originalmente en 1983. En sus Cuentos al amor de la lumbre 1 (Rodríguez, 2018) se evidencia que La princesa mona mantiene similitudes argumentales con La Mica, de Lyra (2020); La adivinanza del pastor con El tonto de las adivinanzas, de Lyra (2020) o El burro cagaduros, de Rodríguez (2018), con Escomponte perinola, de Lyra (2020). En Cuentos al amor de la lumbre 2 (Rodríguez, 2009) se observa que La casita de turrón tiene un argumento semejante al de La casita de las torrejas, de Lyra (2020); Juan Soldado, Cristo y San Pedro, con Uvieta, de Lyra (2020) o El lobo cree que la luna es de queso, de Rodríguez (2009) con un fragmento de Tío Conejo y tío Coyote, de Lyra (2020). Y precisamente, el personaje de tío Conejo se hace acreedor de otra fuente, la de un autor norteamericano que escuchó en su infancia, cuentos de origen africano.

Lyra, en una nota introductoria de la revista San Selerín (1913, mayo 1) y en el ensayo La Cenicienta, de 1914, recopilado en Relatos escogidos (Lyra, 1999), se refirió a los cuentos de Joel Chandler Harris. También, en el inventario de libros de la Escuela Maternal de Costa Rica, institución que dirigió María Isabel Carvajal (González, manuscrito inédito de 1925), se registró un ejemplar del libro Nights With Uncle Remus de ese mismo autor.

Según explicó Brasch (2000), Chandler Harris fue un escritor y periodista nacido en Georgia, Estados Unidos, en 1845. Visitó barriadas y casas en las que habitaban personas afroamericanas que vivían en condición de esclavitud. Así conoció cuentos y leyendas que se narraban en la lejana África, cuyo protagonista solía ser un conejo o una liebre, que destacaba por su picardía y astucia para ganar cualquier contienda. Este personaje pudo llamarse originalmente Somba, Kalulu, Sunguru o Mvundlazana. En la lengua inglesa, fue denominado como Brother Rabbit, o de manera abreviada, Brer Rabbit.

Existe alta probabilidad de que Carmen Lyra haya leído esos cuentos en su lengua original, pues se graduó como maestra trilingüe en el Colegio Superior de Señoritas, razón por la que poseía libros y revistas en español, inglés y francés.

Chandler Harris (1983), décadas antes, le había dado vida a Uncle Remus, el tío Remus, un afroamericano que contaba las aventuras del pilluelo Brer Rabbit. De esa forma, se vislumbra que una historia como The Moon in the Mill-Pond, de Harris (1983), fue contada por Lyra (2020) como Tío Conejo y tío Coyote; Brother Rabbit Ties Mr. Lion, de Harris (1983) como Por qué tio Conejo tiene las orejas tan largas o A Ghost Story, de Chandler Harris (1983) como Tío Conejo y el yurro, de Lyra (2020), aspecto que también da al libro costarricense la cualidad de universalizar esos cuentos de origen africano.

Sin embargo, no solo Carmen Lyra narró cuentos de tío Conejo en América Latina. Debe observarse el minucioso trabajo desarrollado por Cantillano (2002), en la Universidad de Arizona, en el que demostró la existencia de versiones de un mismo cuento en países del continente.

Los veintitrés cuentos, en el libro de María Isabel Carvajal, no guardaron siempre el mismo orden, pues su número fue aumentando en las diferentes ediciones publicadas a partir de 1920. También, en esas ediciones posteriores, aparecieron propuestas de artistas de la gráfica, como se explicará en el siguiente apartado.

\section{NO SIEMPRE FUERON LOS MISMOS CUENTOS}

Se puede afirmar que el libro salió a la luz pública en 1920, pues ese año aparece consignado en el ejemplar de la primera edición hallado en la Biblioteca Nacional de Maestros de Argentina. Asimismo, en Repertorio Americano, (1920, Vol. 1, N 16, p. 245) apareció el siguiente anuncio (ver Figura 1): 


\section{5}

\section{Un libro más de Carmen Lira}

Acaban de salir de los tipos de la Imprenta Alsina los Cuentos de mi tia Panchita, cuentos populares costarricenses, recogidos con habilidad y simpatía por Carmen Lira, que era la llamada a hacerlo.

Son éstos los cuentos:

Los cuentos de mi tía Panchíta. - Tio Conejo comerclantc, - Ia Cucarachita Danalinga. - Salir cou us domingo stete, - La Flor del Olivar. - La mica. - Ist tonto de las adivinanzas, - La sucgra tot Dlabio,-La casita de tas torrejas. - R1 CotonudoLa Negra y la Rulia.-Uvieta.-Por qué tio Conejo tiene las orejas tan largas.Jana, el de la cargaita de lella. - Bt Pitjaro Dulce Encauto. Tio Conejo y tio Coyote.

El librito resultı de lo más apropiado para los niños, por la sustancia de los cuentos en sí, como por la riqueza de expresiones del lenguaje popular en que estát contados. Es la ocasión de que padres de familia y maestros los adquieran; constituyeu un precioso regalo para los nifios.

A E 1.00 el ejemplar se ven. den en la Administración del REPERTORIO y en la LIBRERIA Tormo. En la doceua se hace un descuento de $20 \%$.

FIGURA 1

Publicidad de la primera edición

Fuente: Anónimo (1920, p. 245)

Se registran, además, dos ediciones publicadas en 1936 que cuentan, por primera vez, con las ilustraciones de Juan Manuel Sánchez. Una de ellas es rústica e impresa a una sola tinta de color negro (1936a). La otra tiene tapas duras y las mismas ilustraciones se visualizan con tintas de colores como el verde, el vino, el azul o el naranja (1936b). De esa forma empieza a conceptuarse a Los cuentos de mi tía Panchita no solo como texto literario pues, a partir de entonces, se convierte en una obra, en la cual se observan características gráficas que se vuelven usuales en libros publicados en Costa Rica, principalmente entre las décadas del 30 y el 70 , del siglo XX.

Para la artista Vicky Ramos (V. Ramos, comunicación personal, 21 de marzo de 2020), los dibujos de Sánchez tienen varias influencias como la de origen precolombino, las líneas curvas que se entrelazan formando grecas, figuras humanas y animales redondeados y, aunque su línea es muy depurada, se percibe en ella la presencia del modernismo o el Art noveau propio de inicios del siglo XX. Sus trabajos acompañaron, de 1936 en adelante, libros de Carlos Luis Sáenz, Carlos Gagini, Adela Ferreto o Lilia Ramos, entre otros destacados nombres de la literatura nacional. También aparecen en revistas infantiles como Triquitraque, la cual empezó a circular a partir de 1936; o Farolito, cuyo primer número apareció en 1949 (ver Figura 2). 


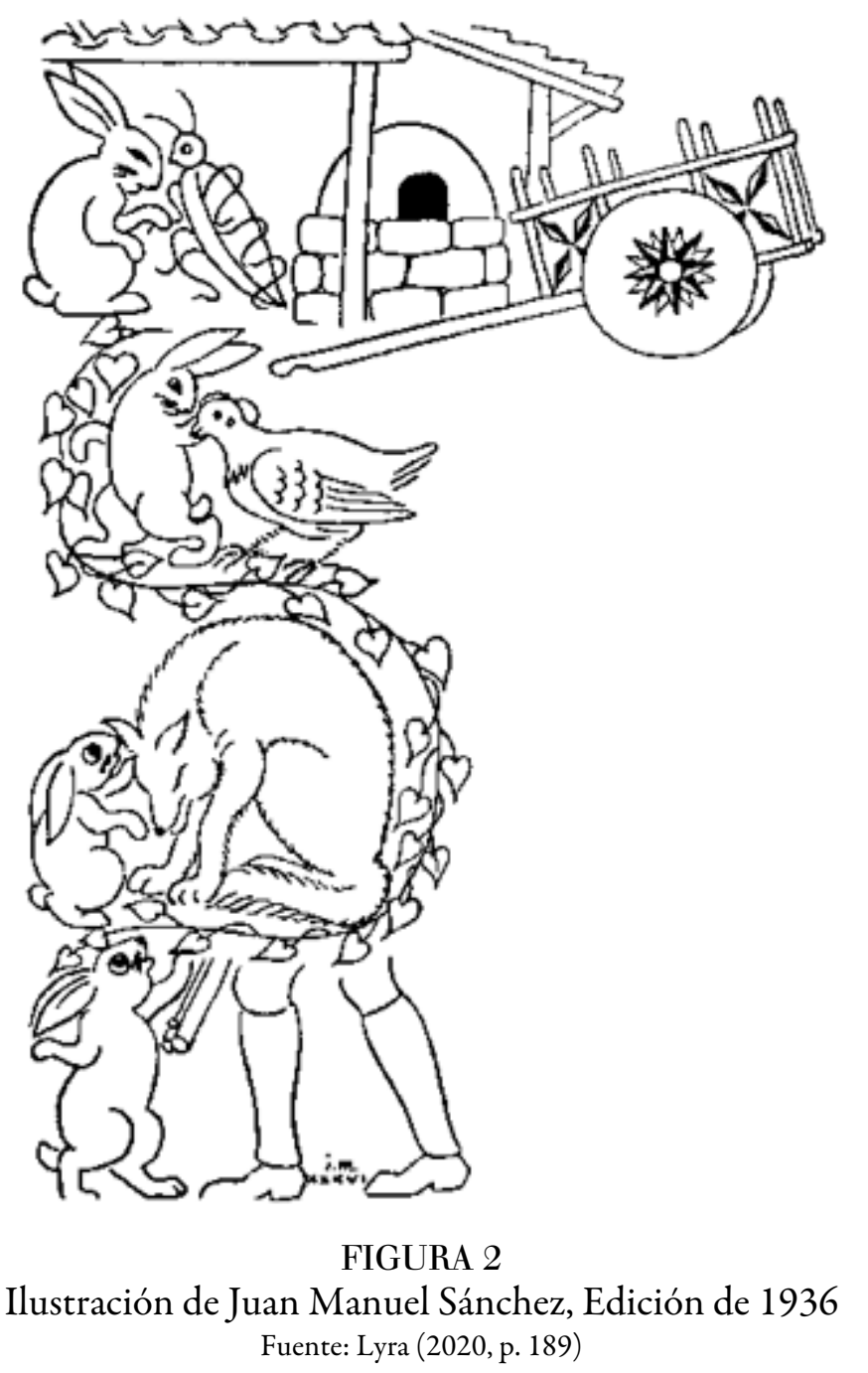

En las dos ediciones (1936a, 1936b) se agregan, a los quince cuentos ya mencionados en la Figura 1, los siguientes: "De cómo tío Conejo salió de un apuro, Tío Conejo comerciante, Tío Conejo y los quesos; Tío Conejo y los caites de su abuela", (Lyra, 1920, mayo 15, p. 300) el cual fue publicado originalmente en Repertorio Americano; “Tío Conejo y el caballo de Mano Juan Piedra, Tío Conejo ennoviado; y Cómo tío Conejo les jugó sucio a tía Ballena y tío Elefante" (Lyra, 1923, agosto 15, pp. 3 - 4), dado a conocer en Selerín.

Como señala Naranjo (2016) después del fallecimiento de la autora, ocurrido en 1949 en México, lejos de su país por razones políticas, existió un proceso de invisibilización de su obra.

Siete años después de su muerte, en 1956, salió a la luz una nueva edición de Los cuentos de mi tía Panchita y allí se registran dos nuevos títulos: Escomponte perinola y Tío Conejo y el yurro. En ese volumen se varió el orden de los cuentos, pues el libro se encontró dividido en dos partes. En la primera se fijaron los trece cuentos, en los cuales no hay un personaje central y en la segunda, los diez cuentos de tío Conejo. Estas dos partes se encontraron escindidas por una página con una ilustración de Juan Manuel Sánchez, en la cual se observó a la tía Panchita sentada en una banca semejante a la que estuvo en la casa de la autora, tal como consta en una foto de 1936 publicada en el anexo fotográfico de Relatos escogidos (Lyra, 1999); en esa misma imagen se aprecia la técnica de puntillismo, la cual no era usual en las imágenes fechadas en 1936.

Estas características inducen a pensar que la ilustración fue elaborada por Sánchez especialmente para la edición de 1956 (ver Figura 3). 


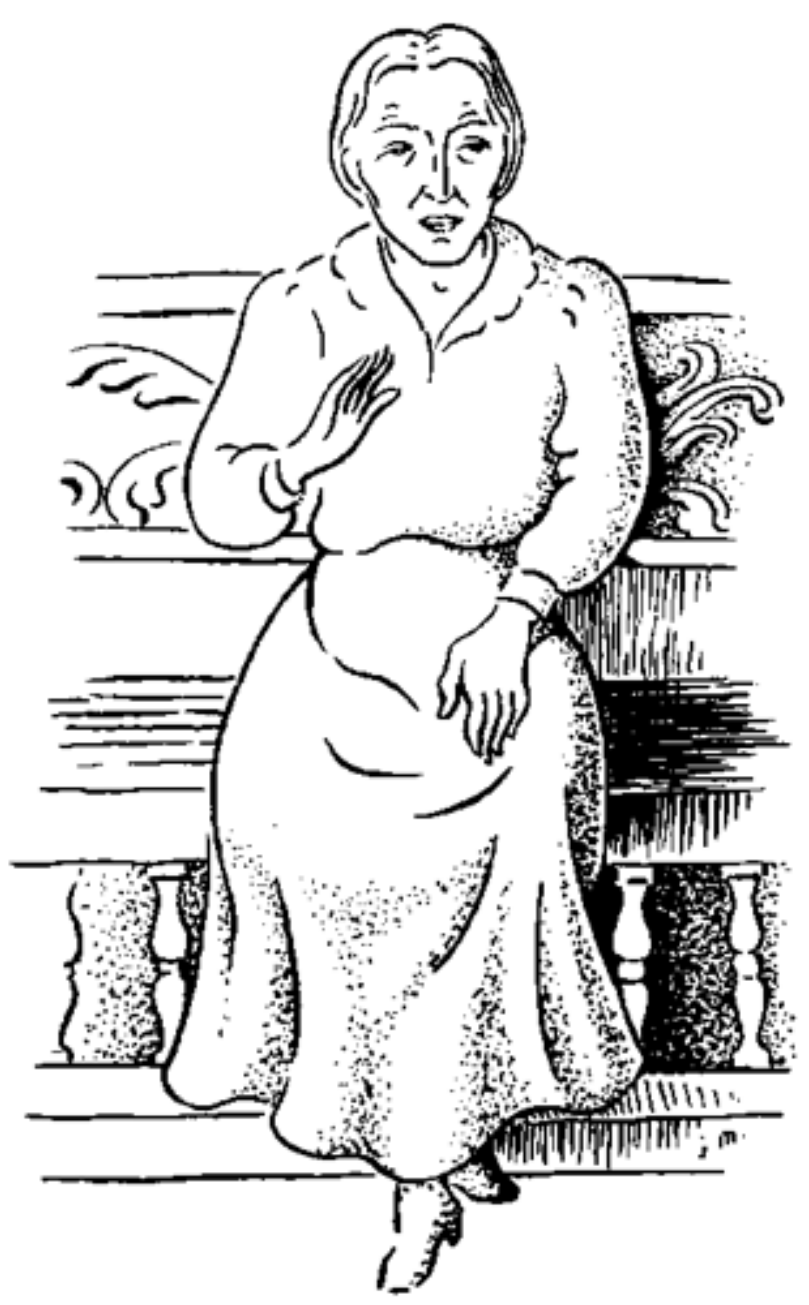

FIGURA 3

Tía Panchita interpretada por Juan Manuel Sánchez Fuente: Lyra (2020, p. 16)

También se agregó, en esa misma edición, una fotografía de la escritora y la caricatura que le dedicó Enrique Hine. En 1966 se publicó un libro semejante, en el cual se expresó: "Nace esta edición de Los cuentos de mi tía Panchita, al igual que la anterior, merced al consejo y ayuda del maestro y querido amigo, Profesor Carlos Luis Sáenz" (Quesada, 1966, p. 1).

Debe reconocerse que el Ministerio de Cultura, Juventud y Deportes ofreció una edición de la obra de Lyra (1975), con un prólogo de su ministra Carmen Naranjo, como una acción llevada a cabo junto con Marjorie Elliott Sypher, entonces primera dama de la República, y las damas del cuerpo diplomático residente en Costa Rica con el fin de fortalecer un Plan de Bibliotecas Rurales. En el preámbulo se expresa: "Carmen Lyra buscaba a todos los niños costarricenses en su corazón amplio, que sigue latiendo con bondad y con inteligencia. Abrió una ventana grande, los llamó con su voz fraternal y acudieron todos" (Naranjo, 1975, p. 1).

La edición que actualmente mantiene en circulación la Editorial Costa Rica, del año 2020, aparte de conmemorar el centenario de la obra, rescata características de las ediciones 1936 y 1956.

Es meritorio destacar el esfuerzo de otras editoriales por llevar, al público, propuestas de encomiable valor gráfico. Por ejemplo, Hugo Díaz preparó ilustraciones en las cuales destacaron sus dotes como caricaturista ya conocido en medios de prensa como Semanario Universidad e ilustrador de libros costarricenses publicados en la década del 70 del siglo XX. Son imágenes, también dibujadas con una sola tinta, las cuales invitan al humor y enfatizan la identidad rural costarricense. Su trabajo fue elaborado originalmente para la Editorial 
Educa (Lyra, 1999) y actualmente la da a conocer la Editorial Legado. Díaz también iluminó una versión de La Cucarachita Mandinga, en 1998, completamente en color (ver Figura 4).

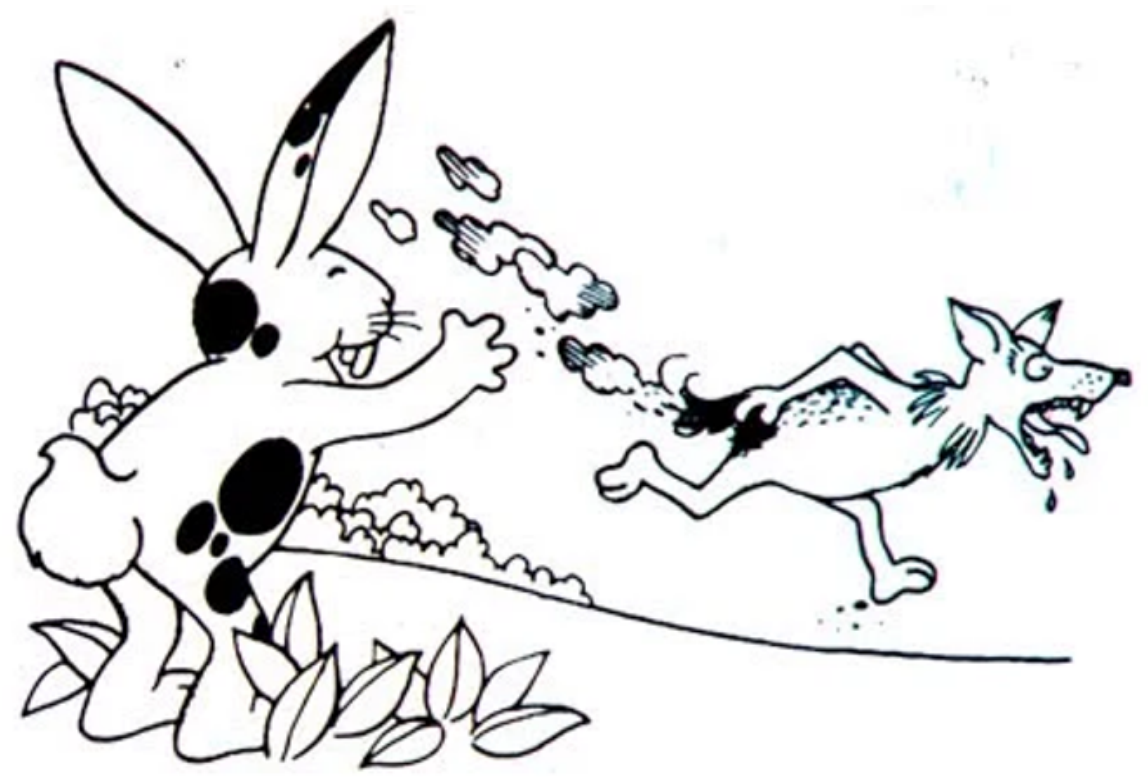

FIGURA 4

Ilustración de Hugo Díaz

Fuente: Lyra (1999, p. 119)

Ruth Angulo ilustró una versión integral de la obra, en 2015, totalmente en color, para la Editorial Uruk. En las diversas imágenes pueden distinguirse algunas características propias de conocidas edificaciones costarricenses tales como el Castillo Azul, el Museo Nacional, la Basílica de Nuestra Señora de los Ángeles, el Templo Católico de Grecia o el Teatro Nacional de Costa Rica. Al respecto debe señalarse que Angulo, aparte de artista gráfica, es arquitecta y, por eso, toma la referencia de esos inmuebles. Asimismo, esta ilustradora, la empresa Casa Garabato y el Centro Costarricense de Producción Cinematográfica publicaron la historieta Las aventuras de tío Conejo (Lyra, 2018) y a partir de 2019 produjeron una serie de cortos animados que merece, por su calidad, un estudio específico (ver Figura 5). 


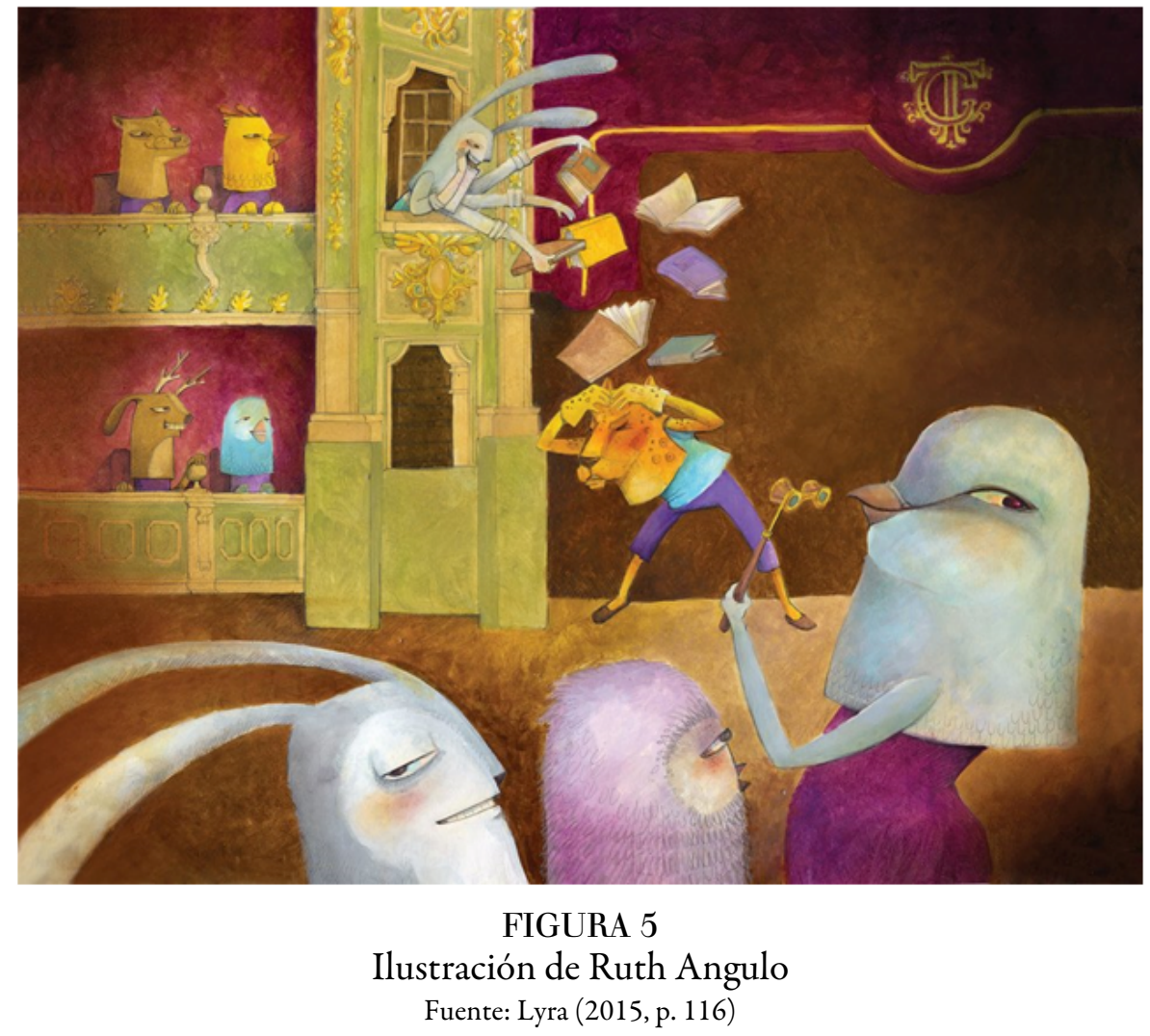

\section{LIBRO CONTROVERSIAL}

Una obra de recopilación de cuentos populares como Los cuentos de mi tía Panchita surge en un contexto en el cual se asociaba la literatura infantil con la tradición de recopilar el folclor, tal como se observa en el ideario de la Cátedra de Literatura Infantil de la Escuela Normal, planteado por García Monge y Lyra, y en la propuesta de selección de textos literarios publicados en la revista infantil San Selerín. Estas expresiones populares no siempre guardaron pretensiones didácticas pues muchas de ellas, aún en el siglo XXI, se pueden considerar politicamente incorrectas. Por eso no guardan como objetivo prioritario la presentación de moralejas; por el contrario, es un texto que conduce al solaz, al entretenimiento, a la ensoñación o a la alegría, pues tal como lo afirma la escritora: “iLa querida viejita que no sabía de Lógicas y Éticas, pero que tenía el don de hacer reír a los niños!” (Lyra, 2020, p. 22), ya que hace uso de un lenguaje que causó estupor hace tiempo y aún hoy puede provocar el sonrojo de quienes guardan pensamientos conservadores.

Nótese que el doctor Fernández Ferraz, en un artículo publicado en el Repertorio Americano, en 1922, sostiene: "Alguien me cuenta que dijo un maestro de escuela no gustar de estos cuentos porque son ejemplo de mal hablar de la \#lengua materna\#” (citado por González y Sáenz, 1977, p. 36). Y no es para menos, el tonto de la adivinanzas expresa con desparpajo: "Bien lo dijo mi mama que buen adivinador de m... sería yo" (Lyra, 2020, p. 29); en el cuento La mica se dice: "Las teticas parecían botoncitos de rosa miniatura" (Lyra, 2020, p. 80); en Tío Conejo y tío Coyote se enuncia: “iAdiós, tío Coyote c... quemao, por amigo de ser casao”, (Lyra, 2020, p. 166); o "Lo que es de esta sí que no escapás, grandísimo tal por cual" (Lyra, 2020, p. 168). Aún en nuestros tiempos tales frases podrían causar molestia, especialmente si se encuentran en una obra escrita por una maestra y dirigida a las jóvenes generaciones.

También, en 1920, hubo reacciones de apoyo al libro que recién había salido de imprenta. En Repertorio Americano, el poeta Carlos Luis Sáenz dedicó un poema a Carmen Lyra "con motivo de la publicación de Los cuentos de mi tía Panchita” (Sáenz, 1920 abril 15, p. 267). También, en Repertorio Americano, Magón (1920, 
mayo 15) dirigió una carta desde Nueva York a la autora, en la cual afirmó que él era el iniciador de la literatura costarricense de costumbres y por eso guardaba el derecho de lamentarse o felicitarse por la aparición de nuevos libros del género. En este caso, expresó que estaba "vuelto turumba" (Magón, 1920, p. 299), ya que conoció a la tía Panchita que pudo llamarse Manuela Jiménez, Sunción, Mona, Chedes o Trenidad.

El filósofo mexicano Alfonso Reyes (1920, julio 15) envió desde Madrid al Repertorio Americano, un artículo sobre el relato Domingo siete. Había mantenido inédito ese texto desde 1913 y le pareció oportuno publicarlo con motivo de la aparición del libro de Carmen Lyra, en donde encontró una "deliciosa versión de ese cuento" (Reyes, 1920, p. 356). Este hecho sorprende por la velocidad con la que viajó la información en ese entonces y el prestigio que alcanzó la obra en el contexto internacional.

La popularidad de este libro de cuentos infantiles, aparentemente ingenuos, también trajo un costo social a la autora pues fue "una figura controversial e incómoda en una sociedad conservadora, machista y reaccionaria" (Naranjo, 2016, p. 277). Por ejemplo, en un documento que la Embajada de Estados Unidos de San José envió, en noviembre de 1944, a John Edgar Hoover, director del FBI, se aseguró la peligrosidad de María Isabel Carvajal, ya asumida para ese momento como figura clave del Partido Comunista. Sobre ella se expresó que "Su trabajo mejor conocido es un libro de cuentos para niños, llamado Los Cuentos de mi Tía Panchita (The Stories of my Aunt Panchita) [sic]" (citado por Molina, 1999, p. 9), y así se evidenció que el hecho de gozar de notoriedad entre el público la volvía, al mismo tiempo, una figura sospechosa por su poder de influencia en las jóvenes generaciones.

El tomo de Los cuentos de mi tía Panchita representa una irrupción en la literatura costarricense, pues con ella se inicia la construcción de un corpus dedicado a la niñez, seguido por otras obras que conformaron un canon de la literatura infantil de este país como lo son Cuentos viejos, de María Leal de Noguera, en 1923; El delfin del Corubicí, de Anastasio Alfaro, en 1923; o Navidades, de Carlos Luis Sáenz, en 1929.

De esa manera, leemos estos cuentos, escritos por Carmen Lyra y editados por Joaquín García Monge, como textos fundacionales y políticamente incorrectos, que nos retratan como seres humanos y nos hablan de la necesidad de la aventura, el goce estético, el humor y la magia de la palabra.

Mucho más habría que decir, cien años después de su primera edición, pero la palabra queda abierta a las futuras generaciones. Así que nos metemos por un huequito y no salimos por otro, para que Carmen Lyra nos cuente otro.

\section{ReFERENCiAS}

Andersen, H. C. (15 de octubre, 1912). Almendrita. Revista San Selerín, 6 (I), 7 - 14. Recuperado de https://bit.ly /2TPP6Qq

Anónimo. (1 de junio,1913). Tío Conejo ayuda a tía Tortuga. Revista San Selerín, 13 (1), $14-15$. Recuperado de h ttps://bit.ly/2TPP6Qq

Anónimo. (1 $1^{\circ}$ de agosto, 1913). El caballo de tío Conejo. Revista San Selerín, 14 (I), 4 - 6. Recuperado de https://b it.ly/2TPP6Qq

Anónimo. (15 de setiembre, 1913). Mister Caballo y tía Zorra. Revista San Selerín, 19(I), 12-14.

Dobles, M. (1984). Panorama de la literatura infantil en América Latina. Caracas, Venezuela: Banco del Libro.

Anónimo. (1 de abril, 1920). Un libro más de Carmen Lira. Repertorio Americano, 1(16), 245.

Anónimo. (15 de abril, 1923). El paseo de la familia de tío Conejo. Revista San Selerín, 2 (II), 12 - 14. Recuperado de https://bit.ly/2TPP6Qq

Anónimo. (15 de junio, 1923). Tío Conejo y compañía. Revista San Selerín, 6 (II), 17 - 18. Recuperado de https:// bit.ly/2TPP6Qq

Anónimo (15 de junio, 1924). Los primos de tío Conejo se escapan de la escuela. Revista San Selerín, 21 (II), 14 - 16. Recuperado de https://bit.ly/2TPP6Qq 
Apaikán. (15 de junio, 1913). Las hadas del bosque. Revista San Selerín, 14 (I), 3 - 5. Recuperado de https://bit.ly/ 2TPP6Qq

Balasch Blanch, E. (2003). Una historia mágica de los cuentos. Madrid: Oberón.

Brasch, W. M. (2000). Brer Rabbit, Uncle Remus and the \#Cornfield Journalist\#. Georgia, USA: Mercer University Press.

Caballero, F. (15 de noviembre, 1912). El Carlanco. Revista San Selerin, 8 (I), 14 - 17. Recuperado de https://bit.l y/2TPP6Qq

Caballero, F. (15 de junio, 1923). El zurrón que cantaba. Revista San Selerín, 5 (II), 5 -7. Recuperado de https://bit .ly/2TPP6Qq

Caballero, F. (1988). Cuentos de encantamiento. Madrid: Espasa Calpe.

Cantillano, O. (2002). Los cuentos de tío Conejo. Revista Letras, 34, pp. 5 - 41. Recuperado de https://bit.ly/2x7i pW2

Chase, A. (1999). Carmen Lyra en su tiempo. En C. Lyra (autora) Relatos escogidos (pp. 505 - 526). San José, Costa Rica: Editorial Costa Rica.

Chandler Harris, J. (1983). The Complete Tales of Uncle Remus. Boston: Houghton Mifflin Company.

Coloma, L. (1911). Ratón Pérez. Cuento infantil. Recuperado de https://bit.ly/2xGh5tt

Díaz, D. (19 de abril, 2020). Cuentos de mi tía Panchita: el libro de $\mathbb{C 1}$ que se volvió un clásico. Revista Dominical, Periódico La Nación, 8-11.

Dengo, M. E. (2011). Tierra de maestros. San José: Editorial UCR.

Dengo, O. (2015). La obra completa de Omar Dengo 1888 - 1928. San José, Costa Rica: Editorial Costa Rica.

Ferrero, L. (1988). Pensando en Garcia Monge. San José, Costa Rica: Editorial Costa Rica.

Ferreto, A. (1984). Las fuentes de la literatura infantil y el mundo mágico. San José, Costa Rica: Instituto del Libro; Ministerio de Cultura, Juventud y Deportes.

Gavaldá, J. (7 de mayo, 2019). Luis Coloma y el Ratoncito Pérez, el cuento que nació como regalo para una reina. Revista Historia National Geographic, 1-1. Recuperado de https://bit.ly/2U6rQwB

González, L. (1925). Historia de la Escuela Maternal. [Manuscrito inédito]. San José, Costa Rica: Archivo Nacional de Costa Rica

González, L. (2006). Escritos. Heredia: Editorial EUNA.

González, L. y Sáenz, C. L. (1977). Carmen Lyra. San José, Costa Rica: Ministerio de Cultura, Juventud y Deportes.

Grimm. (15 de junio, 1913). Hansel y Gretel. Revista San Selerín, 14 (I), 7 - 16. Recuperado de https://bit.ly/2TP P6Qq

Grimm, (15 de julio, 1923). La rana encantada. Revista San Selerin, 8 (II), 12 - 16. Recuperado de https://bit.ly/2 TPP6Qq

Grimm, J. y Grimm, W. (2006). Todos los cuentos de los hermanos Grimm. Buenos Aires: Antroposófica.

Gullivier, L. (1 de mayo, 1923). Las bodas de la Cucarachita. Revista San Selerin, 3 (II), 15 - 16. Recuperado de ht tps://bit.ly/2TPP6Qq

Leal, F. (2020). Imaginario y LIJ. A propósito de Ratón Pérez. Revista Cuatrogatos, 1-1. Recuperado de https://bit. $\mathrm{ly} / 3 \mathrm{ddg} \mathrm{WwS}_{\mathrm{w}}$

Leal de Noguera, M. (1º de mayo, 1923). Tío Conejo y tía Boa. Revista San Selerín, 3 (II), 7 - 8. Recuperado de htt ps://bit.ly/2TPP6Qq

Lemistre, A. (2011). Carmen Lyra. El cuento de su vida. San José, Costa Rica: Editorial Alma Mater

Lira, C. (1920). Los cuentos de mi tía Panchita. San José, Costa Rica: García Monge y Cía., Editores. Recuperado de https://bit.ly/2VTlToX

Lyra, C. (15 de mayo, 1920). Tío Conejo y los caites de su abuela. Repertorio Americano, 1(19), 300. 
Lyra, C. (15 de agosto, 1923). Cómo tío Conejo les jugó sucio a tía Ballena y tío Elefante. Revista San Selerín, 10, 3 - 4. Recuperado de https://bit.ly/2TPP6Qq

Lyra, C. (1936a). Los cuentos de mi tía Panchita. San José, Costa Rica: Imprenta Española Soley \& Valverde.

Lyra, C. (1936b). Los cuentos de mi tía Panchita. San José, Costa Rica: Imprenta Española Soley \& Valverde.

Lyra. C. (1956). Los cuentos de mi tía Panchita. San José, Costa Rica: Empresa Editora "Las Américas".

Lyra, C. (1966). Los cuentos de mi tía Panchita. San José, Costa Rica: Empresa Editora Litografía e Imprenta Costa Rica.

Lyra, C. (1975). Los cuentos de mi tía Panchita. San José, Costa Rica: Ministerio de Cultura, Juventud y Deportes.

Lyra, C. (1998). La Cucarachita Mandinga. San José, Costa Rica: Editorial EDUCA.

Lyra, C. (1999). Los cuentos de mi tía Panchita. San José, Costa Rica: Editorial Educa.

Lyra, C. (1999). Relatos escogidos. San José, Costa Rica: Editorial Costa Rica.

Lyra, C. (2015). Los cuentos de mi tía Panchita. San José, Costa Rica: Editorial Uruk.

Lyra, C. (2018). Las aventuras de tio Conejo. San José, Costa Rica: Editorial Costa Rica.

Lyra, C. (2020). Los cuentos de mi tía Panchita. San José, Costa Rica: Editorial Costa Rica.

Magón. (15 de mayo, 1920). De Magón a Carmen Lira. Repertorio Americano, 1(19), 299.

Mistral, G. (15 de mayo, 1923). Caperucita Roja. Revista San Selerín, 4 (II), 8 - 9. Recuperado de https://bit.ly/2T PP6Qq

Molina, I. (1999). Un pasado comunista por recuperar, Carmen Lyra y Carlos Luis Fallas. En C. Lyra y C.L. Fallas (Autores) Ensayos políticos (pp. 10 - 71). San José, Costa Rica: Editorial de la Universidad de Costa Rica.

Mora. A. (1998). El ideario de don Joaquin García Monge. San José, Costa Rica: Editorial Costa Rica.

Naranjo, C. (1975). Carmen Lyra y la invitación a la lectura. En C. Lyra, (Autora) Los cuentos de mi tía Panchita (pp. 1 - 2). San José, Costa Rica: Ministerio de Cultura, Juventud y Deportes.

Naranjo, G. (2016). Literatura infantil y juvenil. Génesis, contexto y evolución sociocultural. San José, Costa Rica: EUNED.

Oconitrillo, E. (1980). Los Tinoco 1917 - 1919. San José, Costa Rica: Editorial Costa Rica.

Peña, M. (2009). Historia de la literatura infantil en América Latina. Madrid: Fundación SM.

Peña, M. (7 de julio, 2020). Fernán Caballero: una anciana que contaba cuentos. Revista Tantagora, 18, 1 - 10. Recuperado de https://bit.ly/2TRNTZe

Pérez, A. (2012). Origen y evolución de la bibliotecología en Costa Rica. San José, Costa Rica: Colegio de Bibliotecarios de Costa Rica.

Pérez, M. (Enero - Junio, 1985). La literatura infantil en Costa Rica (1900 - 1984), y el mundo mágico de Adela Ferreto. Káñina, IX (1), 101- 118.

Perrault, C. (15 de abril, 1913). La Cenicienta o el zapatilla de cristal. San Selerín, 10 (I), 1 - 10. Recuperado de ht tps://bit.ly/2TPP6Qq

Perrault, C. (15 de julio, 1913). La Bella Durmiente del bosque. San Selerin, 15(I), 9 - 16. Recuperado de https://b it.ly/2TPP6Qq

Quesada, G. (2017). Carmen Lyra, benemérita de la Patria. Revista Estudios (34), 1 - 7. Recuperado de https://bit. ly/3bzRv7I

Quesada, R. (1966). Prólogo a la quinta edición. En C. Lyra. (Autora) Los cuentos de mi tía Panchita. (p. 1). San José, Costa Rica: Empresa Editora Litografía e Imprenta Costa Rica.

Reyes, A. (15 de julio, 1920). Domingo siete. Repertorio Americano, 1 (23), 355 - 356.

Rodríguez, A. (2009). Cuentos al amor de la lumbre 2. Madrid, España: Alianza Editorial.

Rodríguez, A. (2018). Cuentos al amor de la lumbre 1. Madrid, España: Alianza Editorial.

Rubio, C. (24 de marzo, 2018). Cien años de sembrar literatura infantil en Costa Rica. Áncora, La Nación, 3C. Recuperado de https://bit.ly/2KTSdBC 
Rubio, C. (2019). Carmen Lyra, maestra. Tras las huellas de un eclecticismo pedagógico. Revista Educación, 43(2), 1 - 22. Recuperado de https://bit.ly/2w7oTUz

Saénz, C. L. (15 de abril, 1920). A Carmen Lira. Repertorio Americano, 1(17), 267

San Selerín, (1 de agosto, 1912). Portada. San Selerín, 2(I), 1. Recuperado de https://bit.ly/2TPP6Qq

San Selerín. (1 ${ }^{\circ}$ de mayo, 1913). Aventuras de tío Conejo. Revista San Selerín, 11(I), 14. Recuperado de https://bit $.1 y / 2 \mathrm{TPP} 6 \mathrm{Qq}$

San Selerín. (1 de mayo, 1913). El viejo de la montaña. Revista San Selerín, 11(1), 14 - 16. Recuperado de https:// bit.ly/2TPP6Qq

\section{Notas}

[1] El profesor Daniel Bojorge Mata encontró un ejemplar, de esa primera edición, en la Biblioteca Nacional de Maestros, situada en Buenos Aires, Argentina. La obra se encuentra disponible en Internet.

\section{BY-NC-ND}

